\title{
Effect of Carbon and Nitrogen Source and Concentration on Rock Phosphate Dissolution Induced by Fungi
}

\author{
Laura Osorno (Corresponding author) \\ Dept. Ciencias, Universidad Nacional de Colombia sede Medellín \\ Calle 59A No. 63-20, 050034, Medellín, Colombia \\ Tel: 57-314-675 15665 E-mail: lauraosornobedoya@gmail.com \\ Nelson Walter Osorio \\ Dept. Ciencias, Universidad Nacional de Colombia sede Medellín \\ Calle 59A No. 63-20, 050034, Medellín, Colombia
}

Tel: 574-430-7777 E-mail: nwosorio@unal.edu.com

Received: April 14, 2014 Accepted: May 22, 2014 Published: May 26, 2014

Doi: 10.5296/jab.v2i2.5475 URL: http://dx.doi.org/10.5296/jab.v2i2.5475

\begin{abstract}
Inorganic Phosphate (Pi) is an essential nutrient for plant growth and development, however that most soils have in low availability. To overcome this problem it is necessary to apply high amounts of Pi fertilizers, however this is inefficient and costly. Recently, there is increasing interest in the use of rock phosphate (RP) and microorganisms capable of increasing its agronomic effectiveness as crop fertilizer. However, it is unclear the impact that some critical nutrients such as carbon $(\mathrm{C})$ and nitrogen $(\mathrm{N})$ may have on the effectiveness of the microbial RP dissolution. The aim of this study was to evaluate the effect of $\mathrm{C}$ and $\mathrm{N}$ source and concentration on the RP dissolution by the fungus Mortierella sp. under in vitro conditions. The results indicate that the efficiency to dissolve RP was significantly higher with glucose, followed by arabinose; other sources were ineffective (fructose, sucrose, maltose, cellulose and molasses). On the other hand, $\mathrm{NH} 4 \mathrm{Cl}$ was significantly the most effective $\mathrm{N}$ source, followed by $\mathrm{NH}_{4} \mathrm{NO}_{3}$. By contrast, $\mathrm{KNO} 3$ was ineffective to promote $\mathrm{RP}$ dissolution. The best concentration of glucose was $10 \mathrm{~g} \mathrm{~L}^{-1}$, while for $\mathrm{NH} 4 \mathrm{Cl}$ it was $1 \mathrm{~g} \mathrm{~L}^{-1}$. These findings show that by varying nutrient supply, the RP dissolution reactions can be significantly enhanced.
\end{abstract}

Keywords: Solubilization, Phosphorus, Phosphorus solubilizing microorganisms 


\section{Introduction}

Inorganic Phosphate $(\mathrm{Pi})$ is an essential macronutrient for the growth and development of plants (Singh \& Reddy, 2011); however, many tropical soils have low availability of it (Osorio \& Habte, 2013). In order to increase its availability it is necessary to apply high amounts of soluble Pi fertilizer (Reddy et al., 2002). Only a small amount of the applied Pi fertilizer is used by plants $(5-10 \%)$ and the remainder fraction is hold in the soil solid phase in insoluble forms (Vassileva et al., 2000; Osorio \& Habte, 2009; Batti \& Yamar, 2010). As a result of that, the $\mathrm{Pi}$ fertilization in these soils is inefficient, expensive practice, and potentially polluting of water (Shigaki et al., 2006).

An alternative for soluble Pi fertilizers is the use of rock phosphate (RP); however, this has low solubility and low agronomic effectiveness (Pramanik et al., 2009). A strategy to increase its effectiveness as Pi fertilizer, the RP is partially acidulated with sulfuric acid or phosphoric acid (Batti \& Yamar, 2010). Unfortunately, this process is expensive and potentially contaminating of the environment (Zapata \& Roy, 2007; Xiao et al., 2008). Recently, there is an increasing evidence that some microorganisms are capable of accelerate the dissolution of RP and have been termed phosphate-solubilizing microorganisms (PSM) (Relwani et al., 2008; Singh \& Reddy, 2011). Among the effective bacterial PSM are Pseudomonas (Bar Yosef et al. 1999), Enterobacter (Vasquez et al., 2000), and Bacillus (Chen et al., 2006). In the case of fungal PSM Penicillium (Wakelin et al., 2004), Aspergillus (Bojinova, 2008), and Mortierella (Zhang et al., 2011; Osorio \& Habte, 2013) are outstanding.

In order to improve the biotechnological applications of PSM in the fertilizer industry to either produce more soluble Pi fertilizers (Bar Yosef et al., 1999) or enhance the effectiveness of the direct use of RP as Pi fertilizer (Osorio, 2011) it is necessary to know the impact of some critical factors (Cunningham \& Kuiack, 1992). Among the most relevant factors that may control the organic acid production, responsible of RP dissolution, are the microbial C and N nutrition (Londoño, 2010; Nisha \& Venkateswaran, 2011; Habte \& Osorio, 2012). We consider that a more efficient use of these natural and finite resources is mandatory since the global P crisis suggests a shortage of the easily mining RP reserves in the next 60-100 years (Dibb, 2004; Gilbert, 2009). The aim of this study was to determine the effect of $\mathrm{C}$ and $\mathrm{N}$ concentration and source of $\mathrm{C}$ and $\mathrm{N}$ to improve the in vitro dissolution of RP by the soil fungus Mortierella sp.

\section{Materials and Methods}

In this study the PSM tested was the fungus Mortierella sp., which is known for its ability to dissolve efficiently RP (Qin et al., 2009; Zhang et al., 2011; Osorio \& Habte, 2013). This fungus was originally isolated from an Andisol of Hawaii by Osorio and Habte (2001). For all studies, the fungus was previously grown on PDA medium for 5 days at $28{ }^{\circ} \mathrm{C}$ and then suspended in sterile distilled water and stored in a refrigerator at $4{ }^{\circ} \mathrm{C}$ for further use at the Laboratory of Ecology and Biogeochemistry the Universidad Nacional de Colombia at Medellin. Samples of commercial RP from Huila, Colombia, were employed after sieving at $250 \mu \mathrm{m}$. This RP contains a $\mathrm{Pi}$ concentration of $12 \%$. Its empirical formula is $\mathrm{Ca}_{9.69} \mathrm{Na}_{0.22} \mathrm{Mg}_{0.09}\left(\mathrm{PO}_{4}\right)_{5.14}\left(\mathrm{CO}_{3}\right)_{0.86} \mathrm{~F}_{2.34}$ (Hamond \& Chien, 1979). 
The in vitro medium consisted of $\left(\mathrm{g} \mathrm{L}^{-1}\right)$ : glucose $10, \mathrm{NH}_{4} \mathrm{Cl} 1.34, \mathrm{KCl} 1.87, \mathrm{CaCl}_{2} .2 \mathrm{H}_{2} \mathrm{O} 0.2$, $\mathrm{MgSO}_{4} .7 \mathrm{H}_{2} \mathrm{O}$ 0.4, and Huila RP 3.5 as the sole source of Pi (Osorio, 2008). Seventy five $\mathrm{mL}$ of this medium was brought to $250 \mathrm{~mL}$ Erlenmeyer flasks and sterilized in autoclave at $120^{\circ} \mathrm{C}, 0.1 \mathrm{MPa}$ for 20 minutes. The flasks were inoculated and then continuously shaken at $100 \mathrm{rpm}, 28^{\circ} \mathrm{C}$ for 7 days.

\subsection{Activity No.1. Amount of Inoculum}

The effect of the amount of inoculum on the RP dissolution was evaluated with grading amounts of a fungal suspension $\left(0,1,2,4\right.$, and $7 \mathrm{~mL}$ per flask) that contained $10^{7}$ colony forming units (CFU) of Mortierella sp. per $\mathrm{mL}$. Other experimental conditions were as described above.

\subsection{Activity No.2. Concentration of Glucose}

Grading concentrations of glucose $\left(5,10,15,20\right.$, and $\left.25 \mathrm{~g} \mathrm{~L}^{-1}\right)$ were prepared in the Erlenmeyer flask contained the culture medium described above. One $\mathrm{mL}$ of the suspension of Mortierella sp. was added (Act. No 1). Other culture conditions were those described above.

\subsection{Activity No.3. Carbon Source}

The effects of $\mathrm{C}$ source on microbial RP dissolution were tested with monosaccharides (glucose, fructose or arabinose), disaccharides (sucrose or maltose), and polysaccharides (cellulose, carboxymethylcellulose or molasse). Based on the results of activity No. 2, C was applied at a concentration of $4 \mathrm{~g} \mathrm{~L}^{-1}$. One $\mathrm{mL}$ of the suspension of Mortierella sp. was added (based on Act. No. 1). Other culture conditions were those described above.

\subsection{Activity No.4. Concentration of Ammonium}

Grading concentrations of $\mathrm{NH}_{4} \mathrm{Cl}\left(0.5,1.0,1.5\right.$, and $\left.2.0 \mathrm{~g} \mathrm{~L}^{-1}\right)$, as the only $\mathrm{N}$ source, were established in the culture medium. One $\mathrm{mL}$ of the suspension of Mortierella sp. was added (based on Act. No. 1); glucose was applied as the only C source (based on Act. No. 3) at a concentration of $10 \mathrm{~g} \mathrm{~L}^{-1}$. The other culture conditions were those described above.

\subsection{Activity No.5. Nitrogen Source}

The effects of $\mathrm{N}$ sources on microbial RP dissolution were tested with $\mathrm{NH}_{4} \mathrm{NO}_{3}\left(0.61 \mathrm{~g} \mathrm{~L}^{-1}\right)$, $\mathrm{NH}_{4} \mathrm{Cl}\left(0.5 \mathrm{~g} \mathrm{~L}^{-1}\right)$, or $\mathrm{KNO}_{3}\left(0.93 \mathrm{~g} \mathrm{~L}^{-1}\right)$. In all treatments $\mathrm{N}$ was applied at a rate of $0.12 \mathrm{~g}$ of $\mathrm{N} \mathrm{L}^{-1}$. Glucose was applied as the only $\mathrm{C}$ source (based on Act. No. 3) at a concentration of $10 \mathrm{~g} \mathrm{~L}^{-1}$. One $\mathrm{mL}$ of the fungal was added (based on Act. No. 1). Other culture conditions were those described above.

\subsection{Variables}

After the incubation period, the medium $\mathrm{pH}$ was determined by a potentiometer (WTW Sentix electrode 81) immerging directly the electrode in the medium. The concentration of Pi $\left(\mathrm{mg} \mathrm{L}^{-1}\right)$ in the culture medium was determined by the blue-molybdate method (Murphy \& Riley 1962) at $890 \mathrm{~nm}$ wavelength with Genesys 20 Thermo Spectronic spectrophotometer after filtration through Whatman No. 42 filter paper and centrifugation (centrifuge Jouan MR $1812)$ at $4000 \mathrm{rpm}(1500 \times \mathrm{g})$ for 10 minutes.

\subsection{Experimental Design}

The experiments were arranged in a completely randomized design (Table 1). Each activity 
had four replicates, including uninoculated controls. Analyses of variance and Duncan multiple range test were used to evaluate the significance of treatment effects ( $P$-value $\leq$ 0.05). Data were analyzed by means of the software STATGRAPHICS centurion version XVI.

Table 1. Experimental design

\begin{tabular}{|c|c|c|c|c|}
\hline $\begin{array}{c}\text { Activity } \\
\text { No. }\end{array}$ & Treatment & Details & Replicates & Statistical Analysis \\
\hline 1 & $\begin{array}{l}\text { Amount of } \\
\text { inoculum }\end{array}$ & $0,1,2,4$, and $7 \mathrm{~mL}$ per flask & \multirow{5}{*}{4} & \multirow{5}{*}{$\begin{array}{l}\text { Independent Anova } \\
\text { and Duncan } \\
\text { multiple range test } \\
\text { were used to } \\
\text { evaluate the } \\
\text { significance of } \\
\text { treatment effects } \\
\text { (P-value } \leq 0.05) .\end{array}$} \\
\hline 2 & $\begin{array}{c}\text { Concentration } \\
\text { of glucose }\end{array}$ & $5,10,15,20$, and $25 \mathrm{~g} \mathrm{~L}^{-1}$ & & \\
\hline 3 & Carbon source & $\begin{array}{c}\text { glucose, fructose, arabinose, } \\
\text { sucrose, maltose, cellulose, } \\
\text { carboxymethylcellulose and } \\
\text { molasses }\end{array}$ & & \\
\hline 4 & $\begin{array}{l}\text { Concentration } \\
\text { of ammonium }\end{array}$ & $0.5,1.0,1.5$, and $2.0 \mathrm{~g} \mathrm{~L}^{-1}$ & & \\
\hline 5 & $\begin{array}{c}\text { Nitrogen } \\
\text { source }\end{array}$ & $\mathrm{NH}_{4} \mathrm{NO}_{3}, \mathrm{NH}_{4} \mathrm{Cl}$ and $\mathrm{KNO}_{3}$ & & \\
\hline
\end{tabular}

\section{Results}

\subsection{Amount of Inoculum.}

Uninoculated flasks exhibited a solution $\mathrm{pH}$ of 7.80, which was significantly higher than the solution $\mathrm{pH}$ of inoculated flasks (Figure 1A). The inoculation with Mortierella sp. decreased significantly $(P \leq 0.05)$ the solution $\mathrm{pH}$. The lowest $\mathrm{pH}$ values were obtained when the medium was inoculated with 1 and $2 \mathrm{~mL}$ of the fungal suspension per flask (pH: 3.15 and 3.11 , respectively), while with the inoculation of 4 and $7 \mathrm{~mL}$ the solution $\mathrm{pH}$ was significantly higher (3.34 and 3.5, respectively). Consequently, the uninoculated flasks had a solution Pi concentration of $1.22 \mathrm{mg} \mathrm{L}^{-1}$ (Figure 1B). Inoculated flasks had solution P levels significantly higher; the magnitude of this effect was greater when the medium was inoculated with $1 \mathrm{~mL}$ of the fungal inoculum per Erlenmeyer $\left(70.89 \mathrm{mg} \mathrm{L}^{-1}\right)$. Larger amounts of inoculum (2-7 mL) generated significantly less soluble Pi and did not differ significantly to each other in this regard $\left(45.00 \mathrm{mg} \mathrm{L}^{-1}\right)$. 


\section{Mll Macrothink Institute ${ }^{\text {TM }}$}

(A)

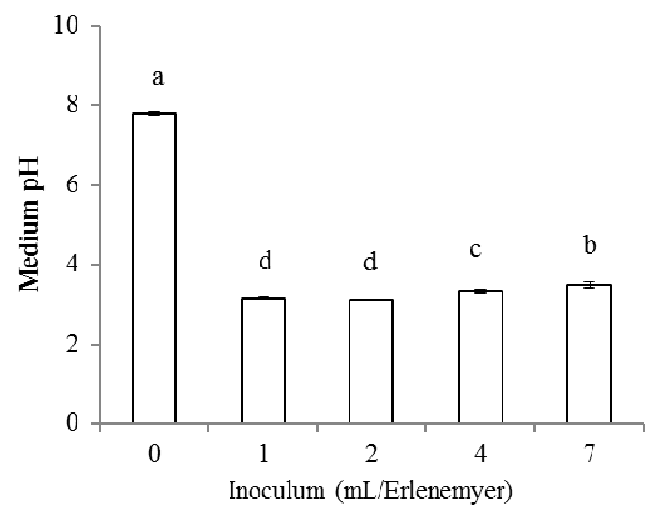

(B)

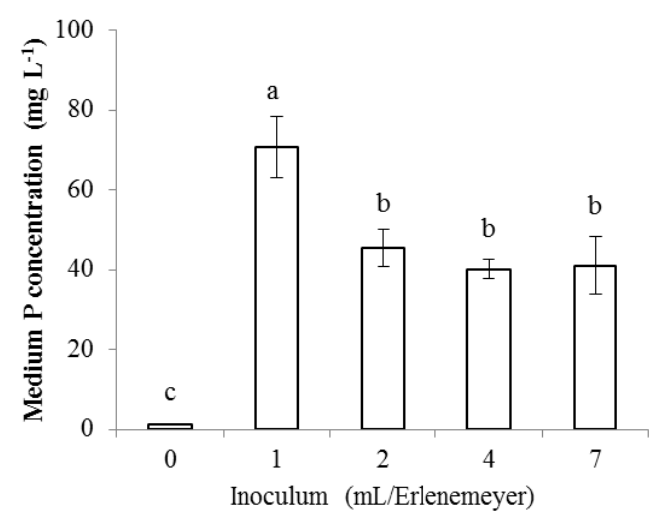

Figure 1. (A) Medium $\mathrm{pH}$ and (B) medium Pi concentration $\left(\mathrm{mg} \mathrm{L}^{-1}\right)$ as a function of the amount of inoculum of Mortierella sp. added into Erlenmeyer flask. Each value is the mean of four replicates. The bars indicate the standard error. Columns with different lowercase letters indicate significant difference between treatments according to Duncan's test $(P \leq 0.05)$

\subsection{Concentration of Glucose}

Uninoculated flasks had solution $\mathrm{pH}$ values $(=7.8)$ significantly higher than inoculated flasks (Figure 2A). The lowest medium $\mathrm{pH}$ were obtained with 10-25 g of glucose per L (3.1), with concentration $5 \mathrm{~g}$ per $\mathrm{L}$ of glucose in medium $\mathrm{pH}$ was significantly higher. Uninoculated flasks had a medium Pi concentration that ranged between 0.24 and $0.30 \mathrm{mg} \mathrm{L}^{-1}$ and did not differ to each other regardless the glucose concentration (Figure 2B). The highest solution Pi concentration was obtained with $10 \mathrm{~g}$ of glucose per L $\left(118.26 \mathrm{mg} \mathrm{L}^{-1}\right)$; glucose concentration below o above this level produced a solution Pi concentration significantly lower.

(A)

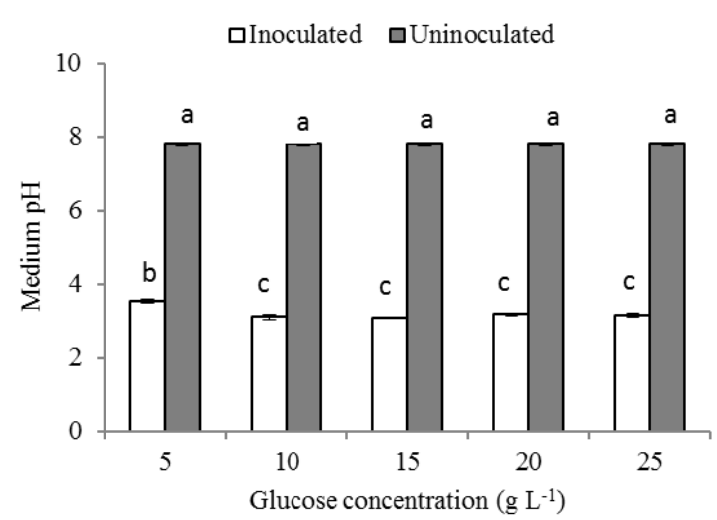

(B)

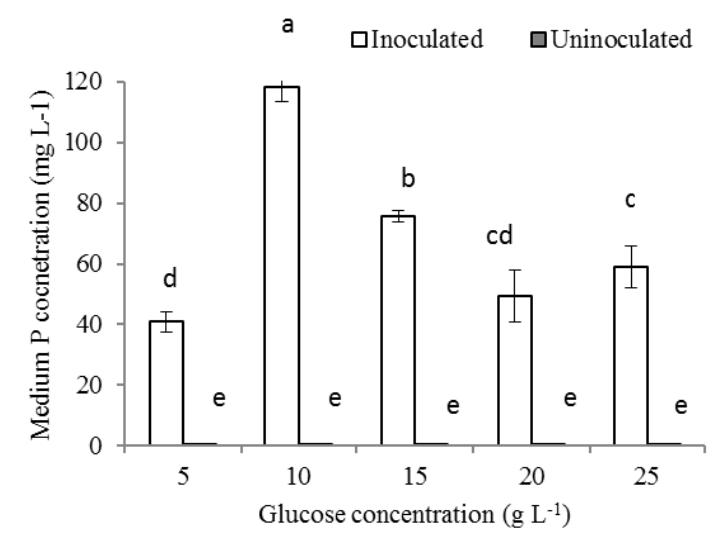

Figure 2. (A) $\mathrm{pH}$ and (b) Pi concentration in solution $\left(\mathrm{mg} \mathrm{L}^{-1}\right)$ in function of the amount of glucose $\left(\mathrm{g} \mathrm{L}^{-1}\right)$ added. Each value represents the average of four replicates. The bars indicate standard deviation. Columns with different small letters indicate significant difference of treatment according to Duncan's test $(\mathrm{P} \leq 0.05)$ 


\subsection{Carbon source}

Uninoculated flasks had medium $\mathrm{pH}$ values (7.7-7.8) significantly higher than inoculated flasks, which were unaffected by the $\mathrm{C}$ source (Figure $3 \mathrm{~A}$ ). By contrast inoculated flasks had significantly lower $\mathrm{pH}$ values, however, the effect in lowering the medium $\mathrm{pH}$ was controlled by the $\mathrm{C}$ source. The decreased in the medium $\mathrm{pH}$ followed the next order: glucose $(2.99)<$ arabinose $(3.6)<=$ fructose $=$ maltose $=$ sucrose $=(6.9)<$ molasses $(7.07)<$ carboxymethyl cellulose (7.15) <cellulose (7.7) (Figure 3A). As a result of that, uninoculated flasks had significantly lower Pi concentration $\left(0.2 \mathrm{mg} \mathrm{L}^{-1}\right)$. The most effective $\mathrm{C}$ source to promote RP dissolution by Mortierella sp. was glucose, the solution Pi concentration was $81.05 \mathrm{mg} \mathrm{L}^{-1}$, followed by arabinose $\left(45.7 \mathrm{mg} \mathrm{L}^{-1}\right.$ ) (Figure 3B). The use of the other $\mathrm{C}$ sources was ineffective to promote RP dissolution.

(A)

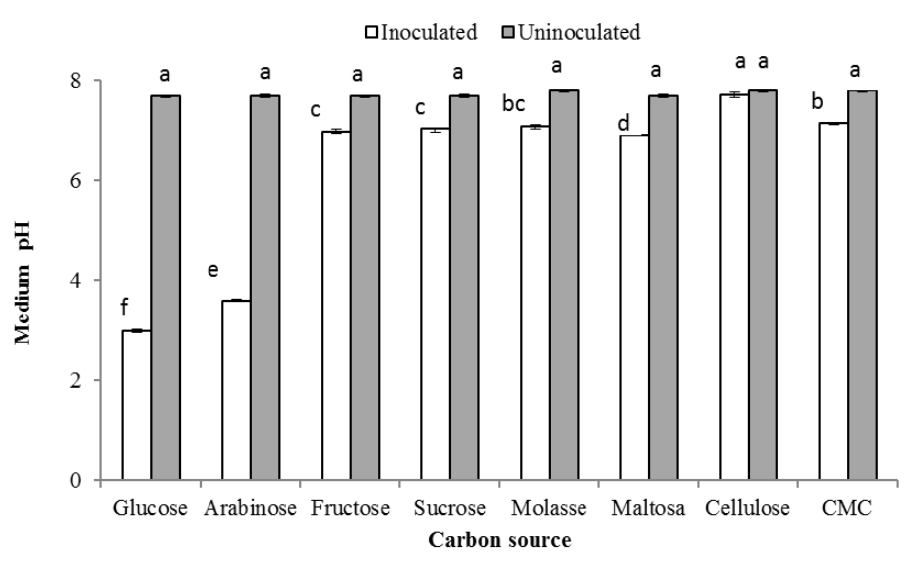

(B)

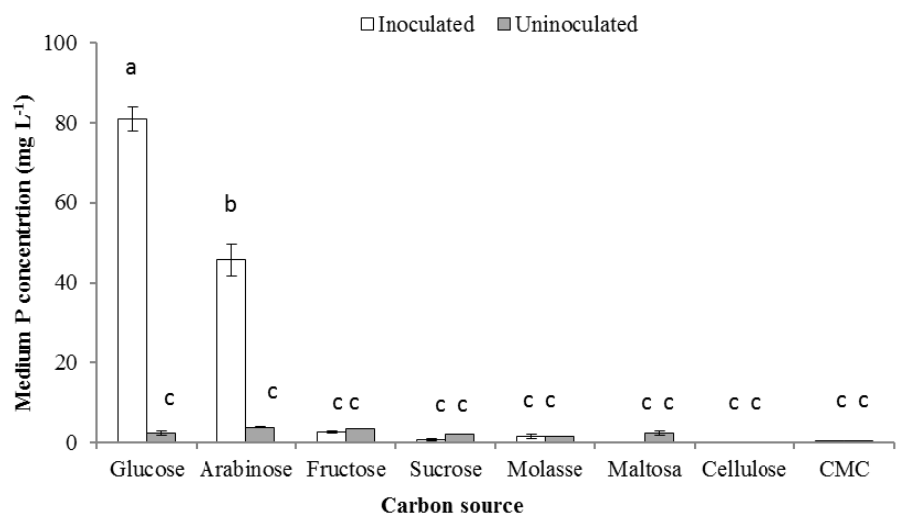

Figure 3. (A) $\mathrm{pH}$ and (b) Pi concentration in solution $\left(\mathrm{mg} \mathrm{L}^{-1}\right)$ depending on the source of C. Each value represents the average of four replicates. The bars indicate standard deviation. Columns with different small letters indicate significant difference of treatment according to Duncan's test $(\mathrm{P} \leq 0.05)$. CMC: carboxymethyl cellulose 


\subsection{Concentration of Ammonium}

Uninoculated flasks had medium $\mathrm{pH}$ values (mean 7.6) significantly higher than inoculated flasks (Figure 4A). In inoculated flasks the $\mathrm{pH}$ decreased but the effect was affected by the level of $\mathrm{NH}_{4} \mathrm{Cl}$; concentrations of $\mathrm{NH}_{4} \mathrm{Cl}$ of $0.5-1.5 \mathrm{~g} \mathrm{~L}^{-1}$ had $\mathrm{pH}$ value of 3.2 , which were significantly lower than that obtained at $2 \mathrm{~g} \mathrm{~L}^{-1}$ (3.3). Consequently, uninoculated flasks had medium Pi concentrations were $0.08 \mathrm{mg} \mathrm{L}^{-1}$ and did not differ to each other regardless the $\mathrm{NH}_{4} \mathrm{Cl}$ concentration (Figure 4B). In the inoculated flasks the highest medium Pi concentration was obtained with $0.5 \mathrm{~g}$ of $\mathrm{NH}_{4} \mathrm{Cl}$ per $\mathrm{L}\left(82.5 \mathrm{mg} \mathrm{L}^{-1}\right)$. The tendency observed was that as $\mathrm{NH}_{4} \mathrm{Cl}$ concentration increased, the medium Pi concentration obtained via $\mathrm{RP}$ dissolution significantly decreased. Thus, with $\mathrm{NH}_{4} \mathrm{Cl}$ concentration of 1.0 and $1.5 \mathrm{~g} \mathrm{~L}^{-1}$ the medium Pi concentrations were 66.1 and $68.3 \mathrm{mg} \mathrm{L}^{-1}$, respectively. At $2.0 \mathrm{~g}$ of $\mathrm{NH}_{4} \mathrm{Cl}$ per L the medium Pi concentration was the lowest $\left(45.5 \mathrm{mg} \mathrm{L}^{-1}\right)$.

(A)

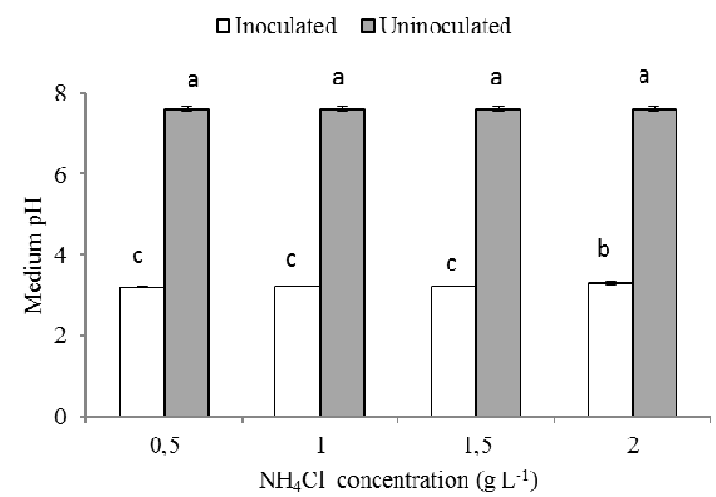

(B)

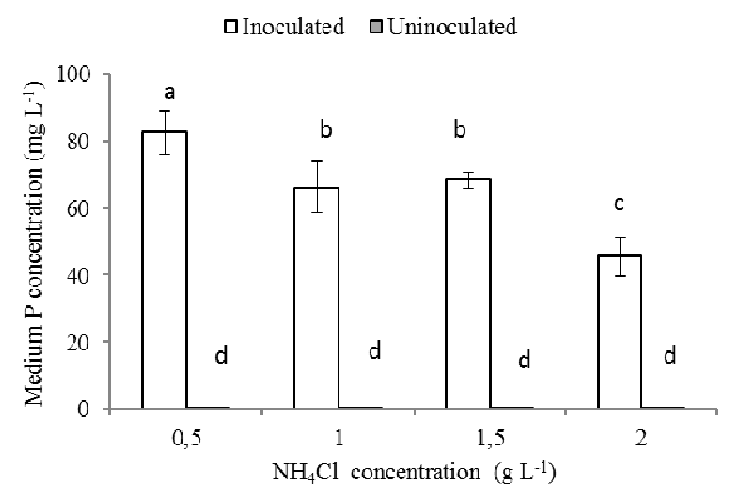

Figure 4. (A) $\mathrm{pH}$ and (b) Pi concentration in solution $\left(\mathrm{mg} \mathrm{L}^{-1}\right)$ in function of the amount of $\mathrm{NH}_{4} \mathrm{Cl}\left(\mathrm{g} \mathrm{L}^{-1}\right)$. Each value represents the average of four replicates. The bars indicate standard deviation. Columns with different small letters indicate significant difference of treatment according to Duncan's test $(\mathrm{P} \leq 0.05)$

\subsection{Nitrogen Source}

Uninoculated flasks had medium $\mathrm{pH}$ values (7.5-7.6) significantly higher than inoculated flasks, which did not differ to each other as a function $\mathrm{N}$ source (Figure 5A). By contrast inoculated flasks had significantly lower $\mathrm{pH}$ values; nevertheless, the magnitude of lowering the medium $\mathrm{pH}$ depended on the $\mathrm{N}$ source. In this way, the medium $\mathrm{pH}$ detected with $\mathrm{NH}_{4} \mathrm{Cl}$ $(\mathrm{pH}=3.2)$ was significantly lower than with $\mathrm{NH}_{4} \mathrm{NO}_{3}(\mathrm{pH}=4.01)$ and this, in turn, significantly lower than with $\mathrm{KNO}_{3}(\mathrm{pH}=6.5)$. As a consequence of this, uninoculated flasks had significantly lower medium Pi concentration regardless of the $\mathrm{N}$ source $\left(0.04-0.07 \mathrm{mg} \mathrm{L}^{-1}\right)$ (Figure 5B). In inoculated flasks, medium Pi concetration depended on the $\mathrm{N}$ source being $\mathrm{NH}_{4} \mathrm{Cl}$ the most effective $\mathrm{N}$ source to promote $\mathrm{RP}$ dissolution and increase Pi concentration (73.41 mg L ${ }^{-1}$ ) followed by $\mathrm{NH}_{4} \mathrm{NO}_{3}\left(33.74 \mathrm{mg} \mathrm{L}^{-1}\right)$. On the other hand, $\mathrm{KNO}_{3}$ was ineffective to promote RP dissolution $\left(0.2 \mathrm{mg} \mathrm{L}^{-1}\right)$. 
(A)

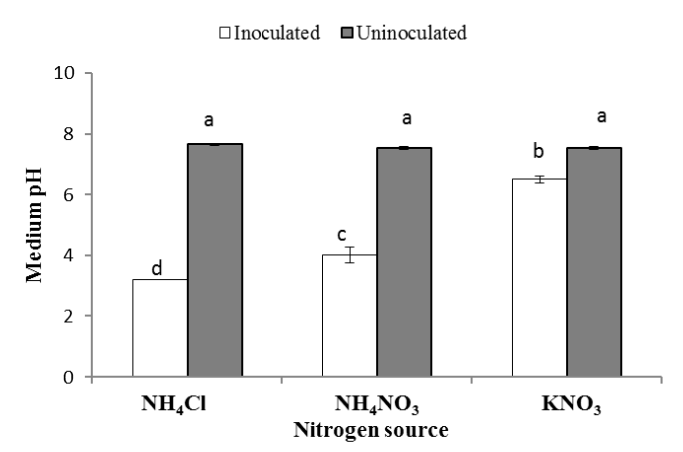

(B)

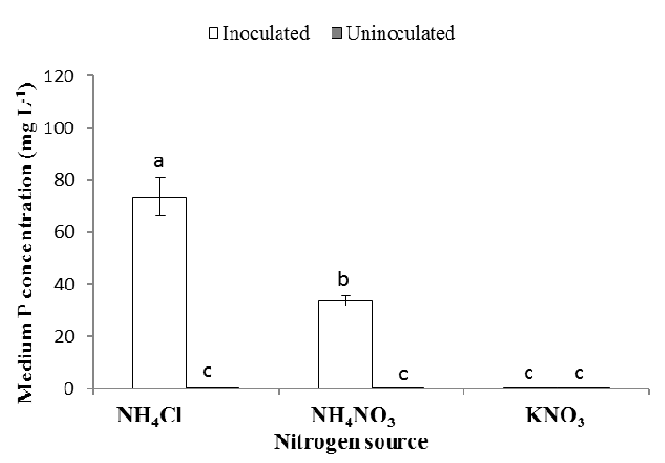

Figure 5. (A) $\mathrm{pH}$ (b) Pi concentration in solution $\left(\mathrm{mg} \mathrm{L}^{-1}\right)$ in function of the $\mathrm{N}$ source. Each value represents the average of four replicates. Bars indicate standard deviation. Columns with different small letters indicate significant difference of treatment according to Duncan's test $(\mathrm{P} \leq 0.05)$

\section{Discussion}

The results clearly show that by changing the amount and source of $\mathrm{C}$ and $\mathrm{N}$ in the culture medium the ability of Mortierella sp. to dissolve RP was improved. Calculations to estimate the maximal efficiency in doing that [EDPR $(\%)=(\mathrm{Pi}$ soluble $\div$ Pi total in the RP $) \times 100$ ] indicate that Mortierella sp. has a value of $18.1 \%$, while in the uninoculated control it was only $0.02 \%$.

Furthermore, the fact that the maximum capacity of Mortierella sp. was detected with the lowest population level $\left(1 \times 10^{7} \mathrm{CFU}\right)(\mathrm{EDPR}=16.9 \%)$ suggest that this fungus is effective using nutrients and producing the required acidity to dissolve RP. By increasing the population density of Mortierella sp. their effectiveness, which may be due to intraspecific competition.

From previously published results (Nahas, 1996; Osorio \& Habte, 2001) and from this study, it is clear that there is an inverse relationship between the medium $\mathrm{pH}$ and the concentration of Pi in solution via RP dissolution. Also, the results indicate that the most effective source of $\mathrm{C}$ for the microbial RP dissolution was glucose, which agrees with results obtained by other researchers in comparable studies (Hameeda et at., 2006; Sharan et al., 2008; Nisha \& Venkateswaran, 2011). For heterotrophic organisms as Mortierella sp. is important to have an adequate source of $\mathrm{C}$ and energy that would meet their metabolic need and produce metabolites like organic acids. In the same way, the amount of glucose in the culture medium appears to be a critical factor in the microbial dissolution of RP, being the EDPR low $(9.7 \%)$ at the lowest level of glucose used $\left(5 \mathrm{~g} \mathrm{~L}^{-1}\right)$, which increased to $28.1 \%$ at the level of $10 \mathrm{~g} \mathrm{~L}^{-1}$, but surprisingly decreased down to $13 \%$ with the highest level of glucose. For Mortierella sp. the oxalic acid production seems to be induced by environmental conditions and non constitutive as in other fungi such as $A$. niger (Madigan, 2004).

Xiao et al. (2008) evaluated the effect of the amount of $\mathrm{C}$ as glucose to optimize the RP dissolution capacity of Pseudomonas expansum, Mucor ramoissimus, and Candida krissii; 
they found that the three microorganisms improve its performance but with different amounts of C. Hameeda et al. (2006) found that the type of source C affected the RP dissolution of Serratia marcescens and Pseudomonas sp., being glucose the best source. Reyes et al. (2006) compared the effect of the $\mathrm{C}$ sources in the RP dissolution capacity of Pseudomonas sp. and Azotobacter sp. and found better results when using sucrose and dextrose. Cerezine et al. (1988) found that the dissolution of fluorapatite by A. niger was favored with fructose and glucose, whereas sucrose, galactose, maltose, and starchdid not promote it. Sharan et al. (2008) evaluated the effect of $\mathrm{C}$ source on the arachidonic acid production by M. Alpine and found that glucose was the best source, other $\mathrm{C}$ sources improved the fungal growth but not the production of this acid.

The increase in the microbial dissolution of RP by raising the concentration of $\mathrm{NH}_{4}{ }^{+}$in the culture has been reported by some authors (Nahas, 2007; Habte \& Osorio, 2012). In this study we consider that $\mathrm{NH}_{4} \mathrm{Cl}$ increases the activity of the proton pump at the cell membrane (Cooke \& Whipps, 1993; Illmer \& Schinner, 1995), which lowered the medium pH, which is required to dissolve RP. It is worth noting that the efficiency of Mortierella sp. to produce acidity was higher with the lowest level of $\mathrm{NH}_{4} \mathrm{Cl}\left(0.5 \mathrm{~g} \mathrm{~L}^{-1}\right)$, at this level the EDPR was $20 \%$. However, Mortierella sp. was ineffective in reducing the medium $\mathrm{pH}$ and dissolving RP when the nitrogen source was $\mathrm{KNO}_{3}$. Similar results with this source of $\mathrm{N}$ have been obtained with the same fungus by Habte and Osorio (2012) at the medium pH of 6.5, where the EDPR was only $0.05 \%$. As the authors reported, this situation may be promoting Pi immobilization by the cells of Mortierella sp. On the other hand, Lu et al. (2011) affirmed that inorganic N sources favor the production of organic acids, whereas organic $\mathrm{N}$ sources favor cell growth.

In addition to the $\mathrm{N}$ source, it is clear that in this study the amount of $\mathrm{N}$ in the medium also had a significant effect on the microbial dissolution of RP. Reyes et al. (1999) found that low concentrations of $\mathrm{NH}_{4} \mathrm{Cl}$ in the culture medium decreased the citric acid production by the fungus $P$. rugulosum and hence the RP dissolution diminished. Kara \& Bozdemir (1998) reported that $1.5 \mathrm{~g} \mathrm{NH}_{4} \mathrm{Cl}$ per liter is the optimal amount for $A$. foetidus to produce gluconic acid in the RP dissolution. The results of the current study coincide with those reported by Cerezine et al. (1988); they found that among several $\mathrm{N}$ sources $\left[\mathrm{NH}_{4} \mathrm{NO}_{3},\left(\mathrm{NH}_{4}\right)_{2} \mathrm{SO}_{4}\right.$, $\mathrm{NH}_{4} \mathrm{Cl}, \mathrm{NaNO}_{3}$, urea, and peptone], $\mathrm{NH}_{4} \mathrm{Cl}$ was the most effective $\mathrm{N}$ source in the $\mathrm{RP}$ dissolution by $A$. niger.

The dissolution of RP is a process that depends on several factors such as the microorganisms used (Narsia \& Patel, 2000) and nutritional, physiological and growth conditions in the culture medium (Adham, 2002; Haq \& Iqbal, 2003; Nahas, 2007). The high concentration of soluble $\mathrm{Pi}$ in the culture medium generated during the incubation is related to the good adaptation of the RP dissolving fungi to the growth environment (Xiao et al., 2008). The use of PSM is as biotechnological approach effective to enhance the agronomic effectiveness of RP for direct use in Pi deficient soils (Osorio \& Habte, 2013) as well as a strategy to obtain more soluble phosphate fertilizers via bioacidification of RP (Stewart \& Howell, 2003; Smith \& Moore, 2005).

\section{Conclusion}


From this study it can be concluded that the in vitro bioacidification of rock phosphate by Mortierella sp. is controlled by the carbon and nitrogen source and amount applied to the culture medium. The best results for this in vitro bioacidification model were obtained with glucose as carbon source ( $10 \mathrm{~g}$ per $\mathrm{L})$ and ammonium chloride as nitrogen source $(0.5 \mathrm{~g}$ per L).

\section{Acknowledgements}

We want to thank COLCIENCIAS (Young Researchers Program), Government of Antioquia department (New knowledge generation program) and the Universidad Nacional de Colombia at Medellín.

\section{Reference}

Association of Official Analytical Chemists. (1984). AOAC (14th ed). Ins Arington Virginia.

AOAC. (1990). Official Methods of Analysis of the Association of Official Analytical Chemists (Volume 1, 15th Edition) Washington.

AOAC. (1998). Official Methods of Analysis of the Association Analytical Chemistry, Inc., Washington DC.

Bello-Pe'rez, L. A., Religion-Acevedo, E., Sa'nchez-Herna'ndez, L., \& Paredes-Lo'pez, O. (1999). Isolation and Partial Characterization of Banana Starches. Journal of Agricultural and Food Chemistry, 47, 854-857. http://dx.doi.org/10.1021/jf980828t

Betancur-Ancona, D., Peraza-Mercado, G., Ordon ez-Moguel, Y., \& Fuertes-Blanco, S. (2004). Physicochemical characterization of Lima bean (Phaseolus lunatus) and Jack bean (Canavalia ensiformis) fibrous residues. Food Chemistry, 84, 287-295. http://dx.doi.org/10.1016/S0308-8146(03)00213-9

Chen, X. B., \& Duan, W. Y. (2003). Capillarygarvity waves due to an impulsive disturbance. Proc. 18th Intl Workshop on Water Waves and Floating Bodies, Carry-Le-Rouet (France).

De Garmo, E. D., Sullivan, W. G., \& Canada, J. R. (1984). Engineering Economy. MacMillan Publishing Company, New York.

FAOSTAT. (2002). FAO Database. Food and Agriculture Organisation of the United Nations. Rome, Italy, 19.2.

Fortuna, James de. (2005). Mangrove Fruit Found In Food Basic. Retrieved from http://www.Tempo interaktif.com.Diakses 2011.

Herath, D. (2009). Sago Starch Modification by Heat Moisture Treatment Technique (HMT) and Its Application in Improving Quality of vermicelli. Master's degree. Bogor Agricultural University. Bogor.

Irawan, M. A. (2007). Carbohydrates. Sports Science Brief, 1(3). www.pssp.lab.com accessed 2011.

Juliano, B. O. (1971). A simplified assay for milled rice amylose measurement. Journal of Cereal Science Today., 16, 334-336 
Juliano, B. O., \& Kongseree. (1968). Physic Chemical Properties of Rice Grain and Starch from line differing in amylose content and gelatinization temperature. J. Agric and Food Chem, 20, 714-717.

Pentury, M. H. (2009). Kajian Potensi Hutan Mangrove Dalam Upaya Penyediaan Pangan Buletin Dinamika Kopertis Wilayah XII, 2, 17-21.

Purnobasuki, H. (2011). Potential as Alternative Food Fruit Mangrove. Retrieved from http://herypurba-fst.web.unair.ac.id/

Pereira, R. C. (2008). Relationship between structural and biochemical characteristics and texture of corn grains. Genetics and molecular research, 7, 498-508. http://dx.doi.org/10.4238/vol7-2gmr446

Poedjiadi. (1994). Fundamentals of Biochemistry. Jakarta: UI Press.

Richana, N., \& Titi, S. C. (2004). Characterization of Physicochemical Properties of Wheat flour starch from tubers and canna bulbs, suweg, ubikelapa and gembili. Postharvest Journal, $1(1), 29-37$

Sadana. D. (2007). Fruit aibon in East Biak Contain High Carbohydrate. Government Official Website of Biak Num for news_.htm

Soebagio, B., Sriwidodo, \& Aditya, S. A. (2007). Testing of Seed Starch Physicochemical properties Durian (Durio zibethinus Murr.,) Natural And Modified By Acid Hydrolysis. Journal. Padjadjaran University.

Waliszewskia, K. N., Maria, A. A., Lui, A. B., \& Jo'se, A. M. (2003). Changes of banana starch by chemical and physical modification of Carbohydrate Polymers, 52, 237-242

Wanma, A. (2007). Utilization of Mangrove Forests (Bruguiera gymnorhiza) L. Lamk For Producing Materials Carbohydrates, Soil Conservation Bulletin tongue.

White, P. J., Abbas, I. R., \& Johnson, L. A. (1989). Freeze thaw stability and Refrigerated storage retrogradation of starches. Starch/Starke, 41, 176. http://dx.doi.org/10.1002/star.19890410505

Yusraini, E., Purwiytno, H., \& Ferry, K. (2007). Characterization of the production process from starch maltodextrin banana (Musa sp) enzymatically with $\alpha$-amylase. Scientific journal, 30(2), 159-168.

\section{Copyright Disclaimer}

Copyright reserved by the author(s).

This article is an open-access article distributed under the terms and conditions of the Creative Commons Attribution license (http://creativecommons.org/licenses/by/3.0/). 